\title{
THE BIOARCHAEOLOGICAL VALUE OF HUMAN MUMMIES WITHOUT PROVENIENCE
}

\author{
LA IMPORTANCIA BIOARQUEOLÓGICA DE MOMIAS HUMANAS \\ SIN CONTEXTO ARQUEOLÓGICO
}

\author{
Bernardo T. Arriaza1 ${ }^{1}$ Larry L. Cartmell ${ }^{2}$, Cora Moragas ${ }^{3}$, Andreas G. Nerlich ${ }^{4}$, Wilmar Salo 5 , \\ Michael Madden ${ }^{5}$, and Arthur C. Aufderheide ${ }^{5}$
}

\begin{abstract}
Thirteen spontaneously (naturally) mummified human bodies with little or no available provenience data were examined by inspection, dissection and tissue chemical analysis. The purpose of the study was to test the hypothesis that useful anthropological/ archaeological and biomedical information could be derived from bodies even when no reliable provenience for recovered mummies is known. Results of studies on these 13 bodies enabled recognition of their cultural identity, and indicated probable extensive exposure to cold marine water (diving?) in the form of external auditory exostoses. Analysis also revealed coca leaf-chewing (or ingesting) practices that probably caused premature antemortem tooth loss. Biological studies identified the presence of Chagas disease (American trypanosomiasis) in six of the bodies, two of which probably died of this infection during the acute stage. Tuberculous osteomyelitis was established in two mummies with one revealing multiple septicemic lesions of the miliar type. Healed pneumonia and osteopenia were present in several others, one with multiple compressed vertebral fractures. We conclude that even mummies without provenience data harbor much recoverable information that can be integrated into anthropological and biomedical databases.
\end{abstract}

Key words: Mummies without cultural context, bioarchaeology, Chagas disease, pneumonia, tuberculosis.

En este estudio se presentan los análisis morfológicos, osteopatológicos y químicos de trece cuerpos con momificación natural cuyo contexto cultural era pobre o no existente. El propósito de este estudio fue verificar la hipótesis de que a pesar de que los cuerpos no presentaban un contexto arqueológico bien definido, estos podían ser muy útiles para investigar importantes problemas bioarqueológicos y biomédicos de la prehistoria local.

Los resultados permitieron ubicar a estos trece cuerpos en un marco cultural y establecer la presencia de exostosis auditivas, condición que se relaciona con actividades marítimas como el buceo en aguas marinas frías. También los resultados indican la masticación y consumo de hojas de coca, actividad que probablemente gatillaba la pérdida prematura de piezas dentales. Además los estudios de laboratorio revelaron la presencia de la enfermedad de Chagas (tripanosomiasis americana) en seis de los casos estudiados, dos de los cuales probablemente murieron de esta infección durante la fase aguda de la enfermedad. Se encontraron además dos cuerpos con osteomielitis tuberculosa, uno mostraba múltiples lesiones del tipo miliar. Varios cuerpos presentaron neumonías curadas y presencia de osteopenia y uno tenía fracturas múltiples de compresión de los cuerpos vertebrales. A pesar de la falta de contexto, los análisis de laboratorio permitieron reconstruir parte del contexto cronocultural y recolectar importante información científica que puede ser integrada a las bases de datos antropológicas y biomédicas.

Palabras claves: momias sin contexto cultural, bioarqueología, enfermedad de Chagas, neumonía, tuberculosis.

Archaeological artifacts separated from their context by looting or other methods are generally considered to have lost most of their archaeological value. Similarly, without their archaeological context, mummified human remains are commonly viewed as capable of providing little information.
However, compared with other artifacts, human mummies available for study constitute a finite number. In the remote areas of northern Chile mummified human bodies periodically come to the regional archaeologists' attention as a result of tomb looting, accidental unearthing during road

1 Instituto de Alta Investigación; Departamento de Antropología; CIHDE/CODECITE, Universidad de Tarapacá, Arica, Chile. barriaza@uta.cl

2 Research Associate of Paleobiology Laboratory, Department of Pathology, Valley View. Regional Hospital, Ada, Oklahoma, USA, 74820.1cartmell@ vvrh.com

3 Av. Chipana, Pasaje 4, N³428, Iquique, Chile. cmoragas@ vtr.net

4 Division of Paleopathology, Department of Pathology, Academic Hospital Munich-Bogenhausen, Munich, Germany. Andreas. Nerlich@extern.lrz-muenchen.de

5 Paleobiology Laboratory, University of Minnesota Duluth Medical School, Duluth, Minnesota, USA, 55812. wsalo@d.umn. edu; mmadden@d.umn.edu;aaufderh@d.umn.edu 
and building construction or similar events other than planned professional excavation. In 1995 thirteen such bodies became available. We studied these in an effort to determine whether anatomical and biochemical examination of such mummified bodies would produce significant information. Our hypothesis was that such investigations would provide data that could be integrated usefully into both the biomedical and anthropological/archaeological database of northern Chile.

\section{Materials and Methods}

\section{The mummies}

Six mummies ranging from no to very limited provenience had accumulated at the San Miguel Archaeological Museum of the Department of Anhropology at the Universidad de Tarapacá in northern Chile (Figure 1). These were labeled CHI-95, T1 through T5, and one, previously included in a prior publication (Arriaza et al. 1995) was labeled SR-1, T-1. An additional seven were curated at the Museo Regional in Iquique, Chile. These were labeled IQU-95, T1 through T7 (Table 1).

\section{The methods}

\section{External examination}

Each body was photographed and sketched as initially received. Wrappings were carefully removed, described and photographed. The exterior of the body was then examined meticulously with special reference to the presence or absence of trauma, head lice (Pediculus capitis), burial position (flexed or extended), intentional cranial deformation, hair style, exostoses of the external auditory canal, tattoos or other abnormalities.

\section{Internal examination}

The anterior chest wall and abdominal wall were carefully removed and individual organs within the thoracic and abdominal cavities were dissected and examined as described in Aufderheide (2003:322-365). Samples averaging 6 × 3 x $2 \mathrm{~cm}$ of the various tissues were excised for biological studies. Bones and soft tissue organs were assigned arbitrary numerical values and the percent of bones present (B\%) and soft tissues (ST\%) estimated. The

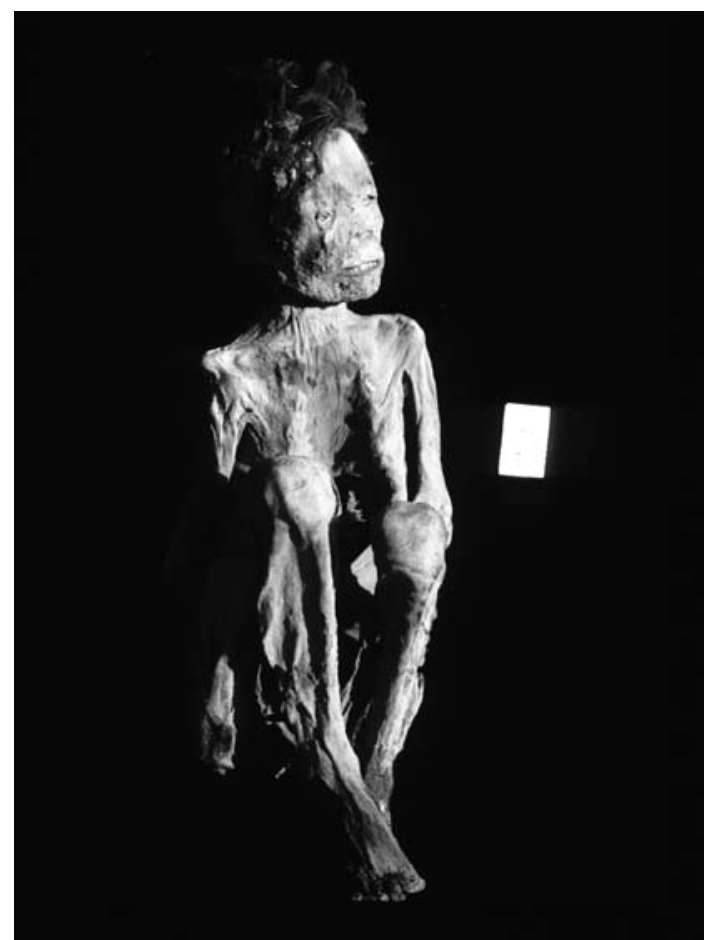

Figure 1 . This is the body of a 14 year-old boy, labeled CHI-95 T-4. Infected heart and liver were found in the thoracic and abdominal cavities upon dissection. Neither colon nor esophagus were dilated. Positive results were obtained in a test for Trypanosoma cruzi DNA on a sample of his colon using ancient DNA methods of molecular chemistry (Aufderheide et al. 2004).

Momia de un niño de 14 años aproximadamente y rotulado como CHI-95 T-4. Su corazón e hígado presentaban un proceso infeccioso. El colon y el esófago no estaban dilatados. Una muestra del colon resultó positivo para un test de ADN para Trypanosoma cruzi usando la química molecular (Aufderheide et al. 2004).

soft tissue index $(\mathrm{ST} \% \div \mathrm{B} \%)$ was calculated and recorded (as detailed in Aufderheide 2003:335) as a measure of the degree of soft tissue preservation. The principal organs were assigned a numerical value of 10 each if present; the total organ sum was recorded (Aufderheide 2003:335). Age and sex were estimated using criteria detailed in Ubelaker (1999:63-95). Stature was estimated using criteria of Genovés (1967).

\section{Biological studies}

Coprolites were examined as suggested by Reinhard et al. (1986). Chemical dietary reconstruction using stable isotope ratios of carbon and nitrogen determined by mass spectrometry were 
Table 1. Chronological placement of the mummies. The numbers in the columns labeled CHI-95 and IQU-95 represent the reference (T) numbers assigned to the mummies of each of these two groups.

Cronología de las momias estudiadas. Los números de la columna rotulados como CHI-95 y IQU-95 representan los números de referencia (T) asignada a cada una de las momias de cada grupo.

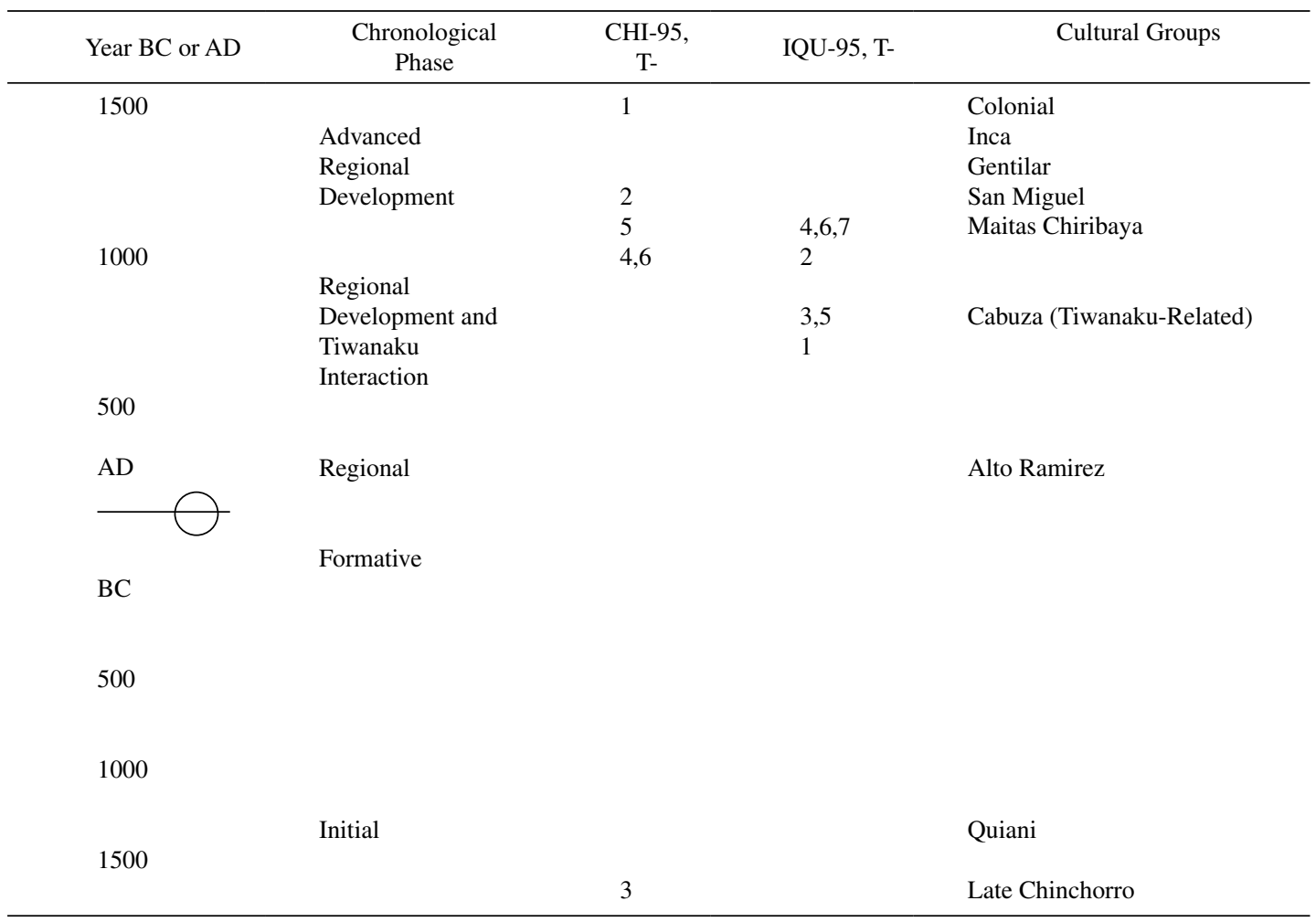

measured and interpreted as detailed by Ambrose (1993) and Ambrose et al. (1997). Hair analysis for cocaine was determined by radioimmunoassay (Cartmell et al. 1991). The presence of Trypanosoma cruzi to establish the infection called American trypanosomiasis (Chagas disease) was determined by methods of molecular biology for ancient DNA (aDNA) (Aufderheide et al. 2004); a similar approach is described in Arriaza et al. (1995) and Zink et al. (2003) to establish the presence of tuberculosis. Very briefly, the amplification of the IS6110 sequence which is an integral part of the Mycobacterium tuberculosis-complex DNA is used to identify positive cases. This is further confirmed by the cleavage with the restriction enzyme Hae-III which has in mycobacterial DNA a single cleavage site.

\section{Results and Discussion}

Table 2 tabulates the findings in these bodies. Ages ranged from 1 to $45 \pm 5$ years at death; three were subadults. The soft tissue index varies but in only one of the 12 bodies in whom this could be estimated is the value less than $50 \%$, indicating remarkably good soft tissue preservation. The organ score values, however, vary considerably, with only 5 bodies generating values of $50 \%$ or more. Of the 10 bodies in whom burial position could be estimated, only one demonstrated an extended position, a feature characteristic of the Chinchorro culture bodies.

\section{The Radiocarbon Dates}

These place each of the bodies into one of the time intervals that compose the developmental chronology classification for northern Chile (Tables 1 and 2). For the CHI-95 group of bodies, T-3 falls into the Initial Period, represented by the Late Chinchorro to Quiani cultures. All the remaining bodies $\mathrm{CHI}-95$ bodies date to the Advanced Regional Development interval (T2, T5) or the Regional Development and 
Table 2. Synthesis of the main findings. I in all rows $=$ Indeterminate. Age range for adults $= \pm 5$ years, for CHI-95, T-4 and SR-1 $= \pm 2$ years and for T-7 $= \pm 0.5$ years. ${ }^{14} \mathrm{C}$ date BP: indicated date is ${ }^{13} \mathrm{C}$-corrected conventional years before the present (AD 1950); ( ) = \pm 1 standard deviation. CDR: chemical dietary reconstruction; apat = apatite. $\% o=$ parts per thousand. Burial position: Flex = flexed; Ext $=$ extended; Dental Path: AML $=$ antemortem loss. Cocaine: $\mathrm{NT}=$ Not tested. $\mathrm{ST} \%=$ percent of soft tissue present. B $\%=\%$ of skeleton present. Soft tissue index $=\mathrm{B} \% \mathrm{o} / \mathrm{ST} \%=\%$ of surviving skeletal tissue that is covered by soft tissue. The radiocarbon specimens were processed at Geochron Laboratories in Cambridge, Massachusetts. The specimen numbers, beginning with CHI-95, T-1 and listed sequentially are GX21171 to GX21175 and beginning with IQU-95, T-1 to T-4 is GX 21176 to GX21179. IQU-95, T-5 specimen no. is GX21183, T-6 is GX21180 and T-7 is GX21181.

Resumen de los hallazgos principales. En cada uno de las filas, $I=$ Indeterminado. Rangos de edades para los adultos $= \pm 5$ años, para CHI-95, T-4 y SR-1 = 2 años y para T-7 = \pm 0.5 años. Los fechados radiocarbónicos ${ }^{14} C$ en años AP conllevan una corrección convencional de ${ }^{13} \mathrm{C}$ y años antes del presente $(A D$ 1950); ( ) = 1 desviación estándar. CDR: reconstrucción

química de la dieta; apat = apatita. \%o = partes por mil. Posición de la inhumación: Flex = flectado; Ext = extendido; patología dental: $A M L=$ pérdida antemortem. Cocaína: $N T=$ No testeado. $S T \%=$ porcentaje de tejido presente. $B \%=\%$ de esqueleto presente. Índice de tejido blando $=B \% \mathrm{~d} T \%=\%$ de tejido óseo presente que está cubierto por tejido blando. Las muestras para radiocarbono fueron analizadas en Geochron Laboratories en Cambridge, Massachusetts. La referencia de los casos, comenzando con CHI-95, T-1 y listados en forma consecutiva son GX21171 al GX21175 y comenzado con IQU-95, T-1 al T-4 son GX 21176 al GX21179. El espécimen IQU-95, T-5 es GX21183, T-6 es GX21180 y T-7 es GX21181.

\begin{tabular}{|c|c|c|c|c|c|c|c|c|c|c|c|c|c|}
\hline \multirow{2}{*}{ Mummy Tomb (T) No. } & \multicolumn{6}{|c|}{ CHI-95 } & \multicolumn{7}{|c|}{ IQU-95 } \\
\hline & $\mathrm{T}-1$ & $\mathrm{~T}-2$ & $\mathrm{~T}-3$ & $\mathrm{~T}-4$ & $\mathrm{~T}-5$ & SR-1 & $\mathrm{T}-1$ & $\mathrm{~T}-2$ & $\mathrm{~T}-3$ & $\mathrm{~T}-4$ & $\mathrm{~T}-5$ & $\mathrm{~T}-6$ & $\mathrm{~T}-7$ \\
\hline Age (yr) & 38 & 45 & 35 & 14 & 38 & 12 & 48 & 48 & 48 & 45 & 20 & 26 & 1 \\
\hline Sex & M & $\mathrm{F}$ & I & M & M & $\mathrm{F}$ & M & $\mathrm{F}$ & $\mathrm{F}$ & $\mathrm{F}$ & $\mathrm{F}$ & $\mathrm{F}$ & M \\
\hline Stature $(\mathrm{cm})$ & 156.5 & 156.6 & 163.5 & 139.4 & 155.0 & NA & 161.6 & 152.4 & 153.4 & 154.4 & I & 157.0 & I \\
\hline Osteopenia & 0 & + & 0 & 0 & 0 & 0 & + & 0 & 0 & 0 & 0 & + & 0 \\
\hline Vertebral fracture & 0 & + & 0 & 0 & 0 & 0 & 0 & 0 & 0 & 0 & 0 & 0 & 0 \\
\hline $\mathrm{St} \% / \mathrm{B} \%$ & $20 / 92$ & $88 / 100$ & $32 / 64$ & $100 / 100$ & $96 / 96$ & I & $100 / 100$ & $80 / 100$ & $88 / 96$ & $60 / 96$ & $8 / 16$ & $100 / 100$ & $56 / 80$ \\
\hline Soft Tissue Index (STI) & 22 & 88 & 50 & 100 & 100 & NA & 100 & 80 & 92 & 63 & 50 & 100 & 70 \\
\hline Organ score & 10 & 25 & 10 & 80 & 65 & 10 & 60 & 50 & 45 & 10 & 0 & 80 & 10 \\
\hline Burial position & Flex & Flex & Ext & Flex & Flex & I & Flex & Flex & Flex & Flex & I & Flex & I \\
\hline Dental Path., AML & 6 & 10 & I & 0 & 0 & 0 & 1 & 4 & 6 & 3 & 0 & 0 & I \\
\hline 14C Date (BP) & $\begin{array}{c}305 \\
(115)\end{array}$ & $\begin{array}{c}585 \\
(115)\end{array}$ & $\begin{array}{l}3566 \\
(100)\end{array}$ & $\begin{array}{c}815 \\
(105)\end{array}$ & $\begin{array}{c}730 \\
(120)\end{array}$ & $\begin{array}{l}910 \\
(70)\end{array}$ & $\begin{array}{l}1310 \\
(125)\end{array}$ & $\begin{array}{l}935 \\
(75)\end{array}$ & $\begin{array}{l}1115 \\
(120)\end{array}$ & $\begin{array}{l}775 \\
(75)\end{array}$ & $\begin{array}{l}1145 \\
(110)\end{array}$ & $\begin{array}{l}770 \\
(75)\end{array}$ & $\begin{array}{l}760 \\
(85)\end{array}$ \\
\hline CDR: $\delta 13 \mathrm{C}$ apat. & -5.60 & -7.28 & -10.18 & -8.19 & -10.06 & NT & -9.41 & -8.80 & -8.16 & -6.80 & -9.79 & -9.54 & -18.39 \\
\hline$\delta 15 \mathrm{~N}$ & 24.81 & 25.02 & 23.72 & 15.40 & 24.28 & NT & 26.02 & 22.46 & 22.46 & 22.42 & 27.62 & 25.25 & 25.25 \\
\hline Auditory exostosis & + & 0 & I & 0 & 0 & 0 & + & 0 & 0 & I & I & 0 & I \\
\hline Cranial deformation & 0 & 9 & I & 0 & 0 & 0 & 0 & 0 & 0 & I & I & 0 & I \\
\hline Lung adhesions & I & 0 & I & + & + & I & 0 & + & + & I & I & + & I \\
\hline Heart pathology & I & I & I & + & 0 & I & 0 & I & I & I & I & I & I \\
\hline Pediculus capitis & 0 & 0 & I & 0 & 0 & 0 & + & + & 0 & I & 0 & + & I \\
\hline Chagas test & 0 & 0 & + & + & + & + & 0 & 0 & + & 0 & 0 & 0 & + \\
\hline Cocaine & NT & NT & NT & NT & NT & 0 & + & 0 & + & + & 0 & 0 & NT \\
\hline Tuberculosis & - & - & - & - & - & + & - & + & - & - & - & - & - \\
\hline
\end{tabular}

Tiwanaku Interaction interval (T-4, SR-1). Within the Advanced Regional Development interval, T2 dates to near the end of that interval. The San Miguel and Gentilar cultural groups occupied that niche and $\mathrm{T} 2$ can be assigned to these. T-5 falls near the middle of this interval and the Maitas Chiribaya was the dominant cultural group for that era. The T-4 and SR-1 bodies have virtually identical dates at the end of the Tiwanaku period and could be members of either Cabuza (Tiwanaku-related) or Maitas Chiribaya group.
The IQU-95 group is chronologically fairly homogeneous although they come from three different coastal sites: Bajo Molle (T-1, 3, 4, 5, and 7) and Los Verdes (T-2) which are south of Iquique; and Pisagua (T-6), which is $140 \mathrm{~km}$ north. Their radiocarbon dates range between 760 and 1,310 BP. Even though three belong to the late phase of the Middle Period (T-1, 3 and 5) and four to the Late Intermediate Period (T-2, 4, 6 and 7), their cultural features are very similar, showing continuity between both periods (except for T-6, whose cultural 
features seemed earlier). The textiles of the group show Tiwanaku influences (similar to Cabuza in Arica) in the tombs of the Middle Period (T-1, 3 and 5) as well as in the ones of the Late Intermediate. Nevertheless, the pottery is not related to Tiwanaku, but to the Late Intermediate Period of Regional Development (Pica-Tarapacá and San Miguel). It seems probable that these people, who were adapted to the coastal environment, were colonies of mother communities living in valleys and oasis in mid altitudes. Through these communities they received indirect influences from the altiplanic centers of the late phase of the Tiwanaku culture, although their own regional development is strongly evident (Moragas 1995).

\section{Biomedical Studies}

\section{Pulmonary pathology}

Of the seven bodies in whom the chest tissues were preserved sufficiently to judge their condition, five had extensive pleural fibrous adhesions. These adhesions testify to the fact that at some time during their life, these five individuals had developed pneumonia from which they recovered completely.

\section{Cardiac pathology}

Mummy CHI-9, T-4 demonstrated a greatly dilated heart, medically classified as dilated cardiomyopathy (Figures 2 and 3). This was a 14 year-old boy whose soft tissue sample provided a positive reaction in the test for Trypanosoma cruzi, the infectious agent for Chagas disease (American trypanosomiasis) (Aufderheide et al. 2004). Death from the chronic form of Chagas disease usually occurs several decades later than age 14 years, so this body most probably represents death due to heart involvement by the trypanosome of Chagas disease in the acute phase with death by heart failure. About $10 \%$ of Chagas disease victims die of heart involvement in the acute phase of the disease, of which this body is an example. Mummy IQU-95, T-7 is an infant who also tested positive for Chagas disease. Although neither heart nor brain was preserved, its age strongly implies it died of acute infection by $T$. cruzi. With the exception of SR-1, the other bodies that tested positive for Chagas disease are older and presumably were in the chronic stage of that condition. The SR-1 mummy was about the same age as CHI-95, T-4 cited above, and a positive test for Chagas disease has the same implications. Unfortunately neither the heart nor other viscera were preserved in that mummy.

\section{Septicemia}

One of the IQU-95 bodies (T-2) developed a fatal infection that spread throughout his body as manifested by multiple purely lytic lesions of many bones including vertebra, scapula and ribs (Figures 4-6). The nature of the lesions is not predictive of the infectious bacterium but is compatible with miliary tuberculosis or a variety of septic bacteria. Therefore, molecular tests of two of these lesions were undertaken in order to identify mycobacterial infection. While in a sample from a rib lesion no positive amplification of mycobacterial aDNA was possible, a sample from an affected vertebral body showed positive reaction. The specificity of the amplification product for mycobacteria of the Mycobacterium tuberculosis-complex was proven by typical restriction enzyme cleavage as previously described (Zink et al. 2003).

\section{Osteopenia with vertebral fractures}

The CHI-95, T-2 mummy demonstrated profound osteopenia resulting in numerous vertebral compression fractures. These occurred in a $45( \pm 5)$ year-old female. Such lesions do occur today, but commonly in women 20 or more years older than this mummy. IQU-95, T-1 and IQU-95, T-6 mummies also had severe osteopenia (though no vertebral fractures) at a similar age as CHI-95, T-2. These cases suggest a study of these populations searching for possible causes for premature osteopenia (including dietary factors that may bind calcium, rendering it nonabsorbable and multiple childbirth at a younger age) might be informative.

\section{Bilateral auditory exostoses}

These lesions were found in two mummies. In IQU-95, T-1 they were present in the only adult male of this group, while in CHI-95, T-1 they occurred in one of two adult males. None occurred in the six adult female bodies in this study. In other coastal groups from this region, these lesions were found principally in adult males and are believed to be the product of diving repeatedly in cold water (Standen et al. 1995). However, evidence for this etiology is not universally considered conclusive, see Aufderheide and Rodriguez-Martin (1998:254-256). 


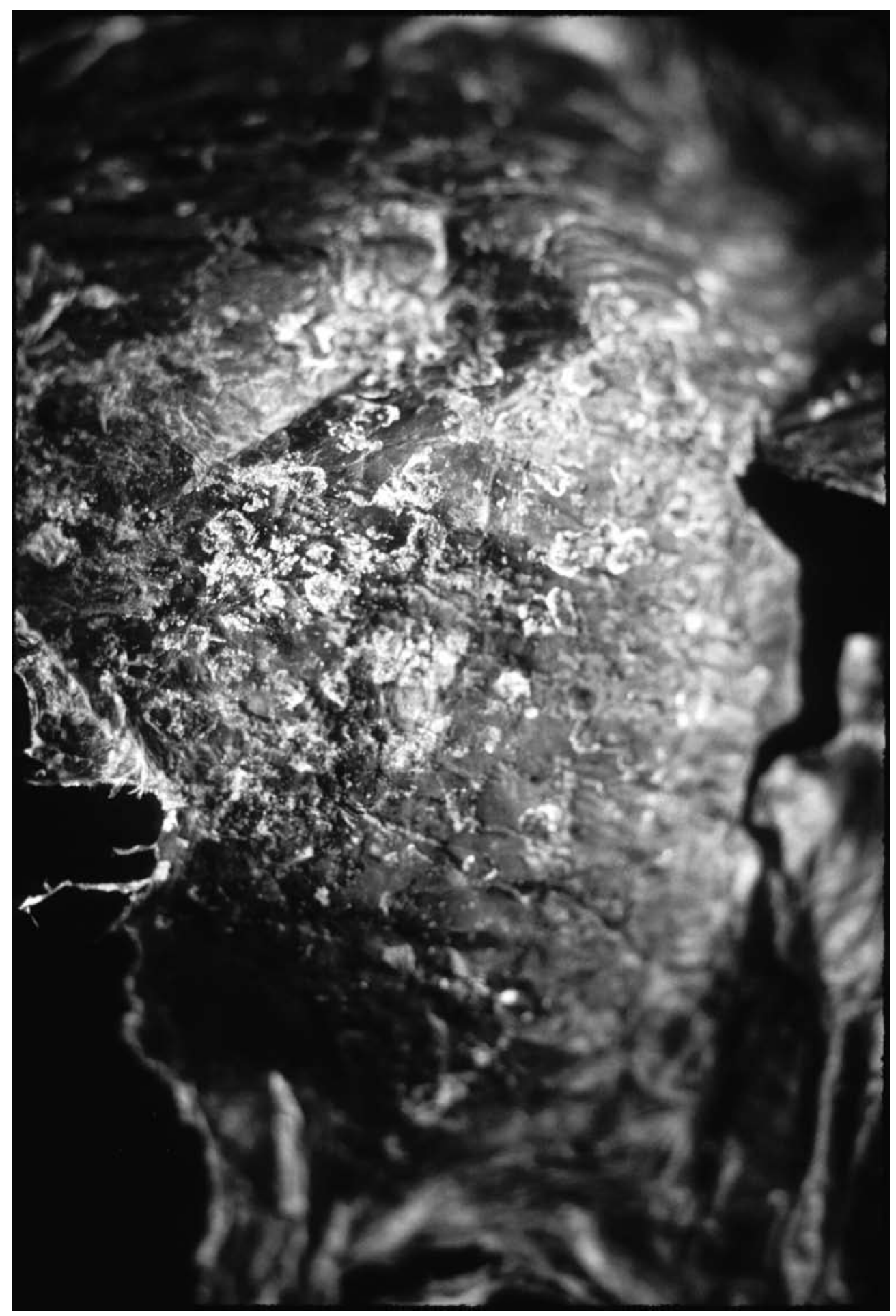

Figure 2. The heart was greatly enlarged (dilated cardiomegaly). The many white spots scattered over the heart's visceral pericardium represent exudate (pus).

El corazón se observa más grande que lo normal (cardiomegalia). Los puntos blancos distribuidos sobre el pericardio representan exudados (pus). 


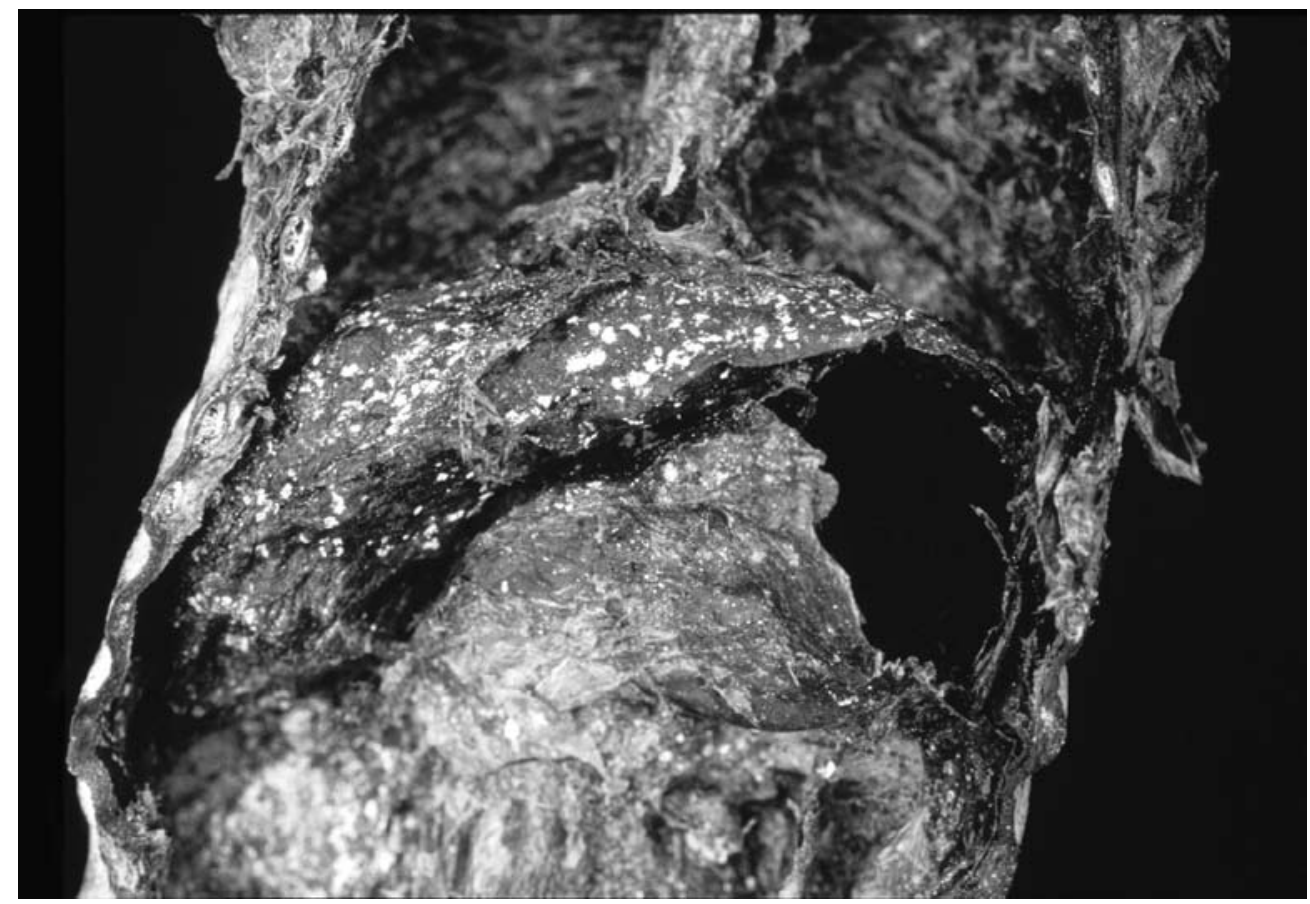

Figure 3. The same infectious exudate seen over the heart was also scattered over the adjacent liver. El mismo exudado infeccioso que se observa en el corazón también está presente en el hígado.

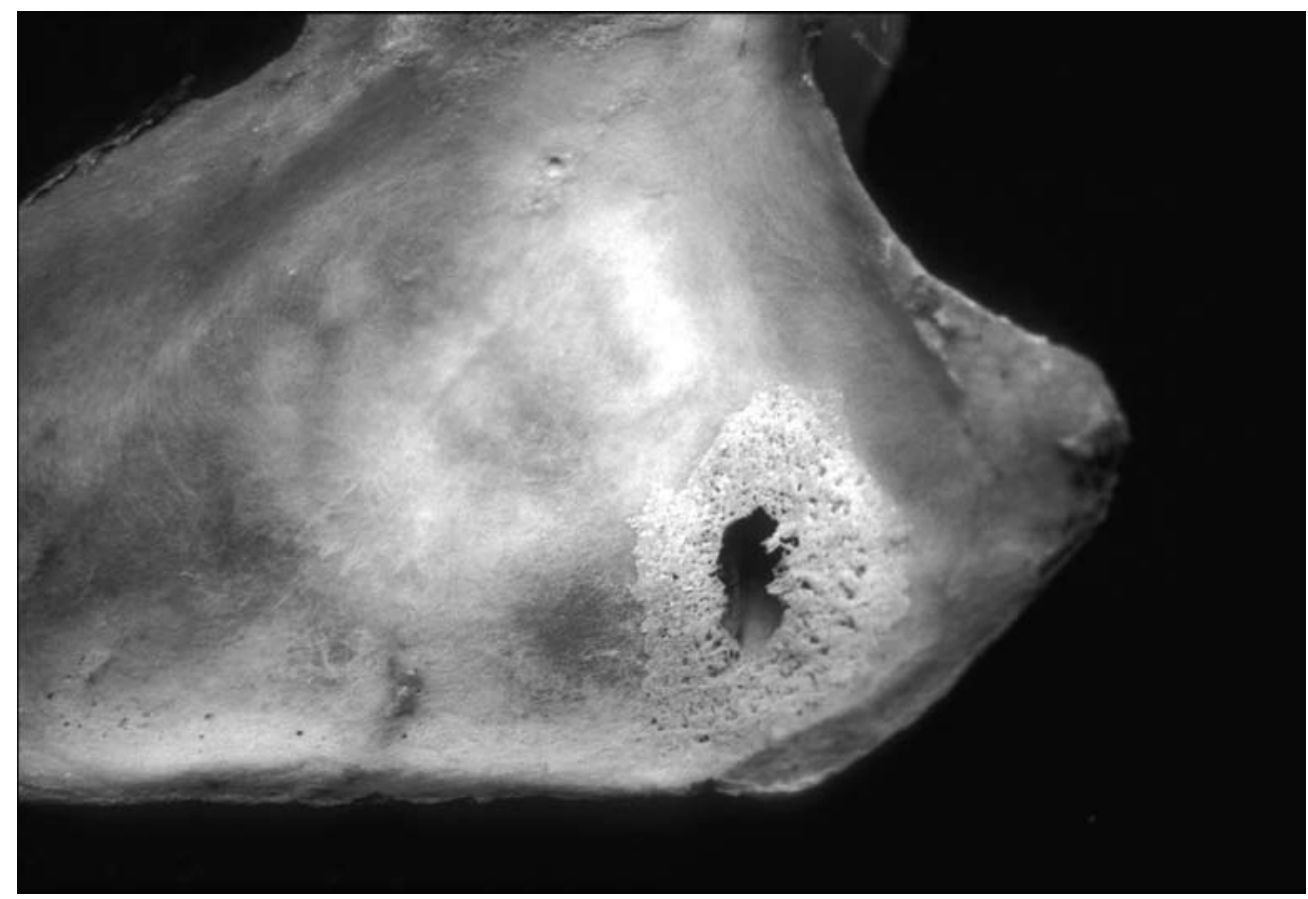

Figure 4. The scapula reveals a lesion characterized by a central lytic area surrounded by a zone of periostitis. Case IQU-95 T-2.

El omóplato presenta una lesión lítica con una zona de periostitis circundante. Caso IQU-95 T-2. 


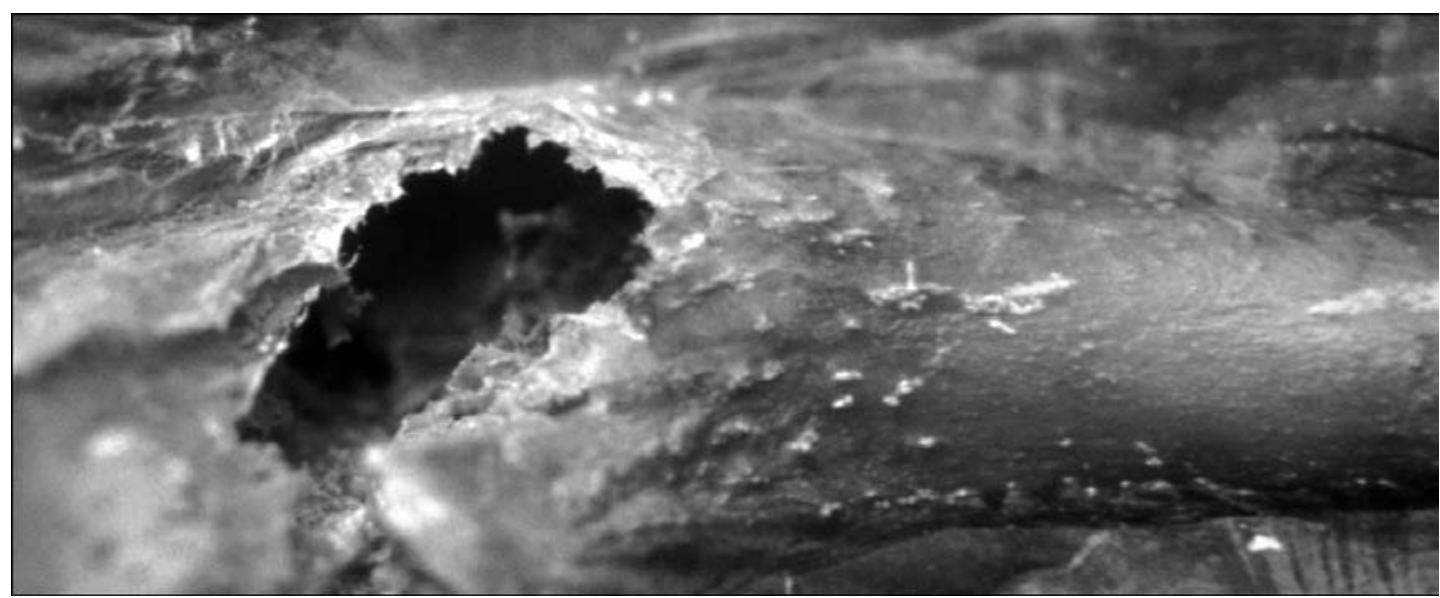

Figure 5. This rib demonstrates a single lytic lesion. The lung was adherent to the edges of this lesion. Costilla con una lesión lítica aislada. El pulmón estaba adherido a los bordes de esta lesión.

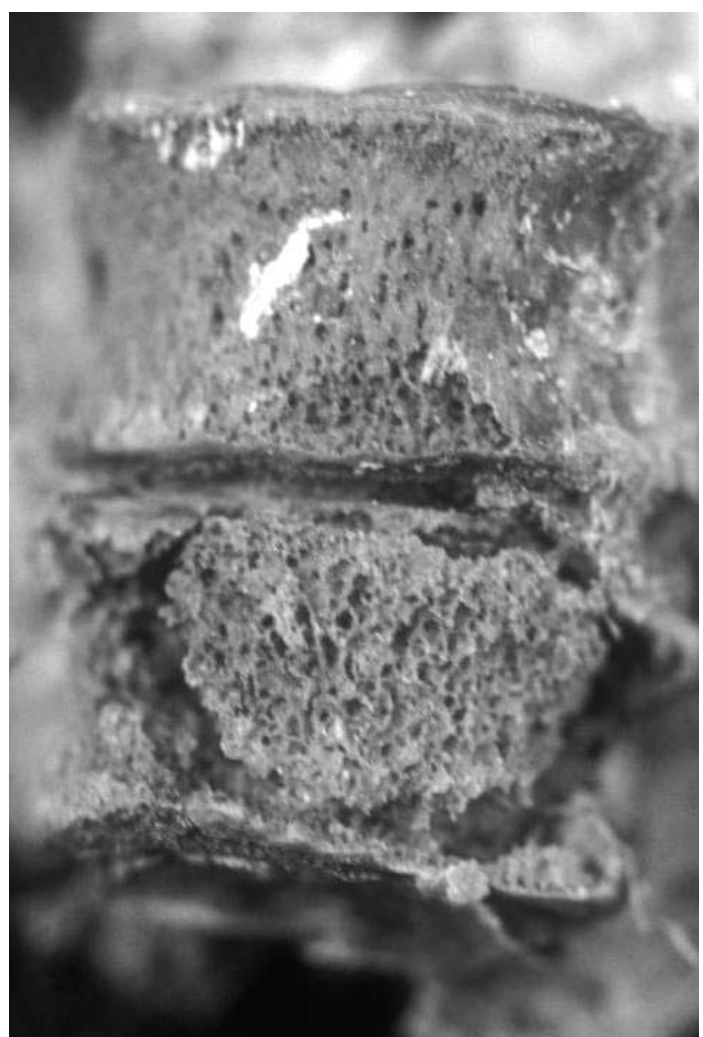

Figure 6. Affected vertebrae showing erosion, one presents destruction of much of the vertebral body without associated new bone formation.

Cuerpo vertebral con erosiones, una presenta erosión en casi toda su superficie anterior pero sin nueva formación ósea.

\section{Pediculus capitis}

Head lice in humans are not known to transmit infectious diseases. Trypanosoma cruzi does not thrive in the intestine of lice, as it does in the intestine of the insect vector for Chagas disease. However, primates indulge in "grooming", a process in which they remove living lice from each other and promptly eat the lice (Hearne 1958). If the lice had recently taken a blood meal from an animal that was parasitemic with $T$. cruzi, it could transmit the disease via oral ingestion of the lice. Such mechanism has been proposed to explain an epidemic of Chagas disease in a research baboon colony (Arganaraz et al. 2001). Such grooming behavior has been observed in some Native American groups, though not in those from South America. Thus, while this sequence of events may be possible, currently it has not been documented.

\section{Cocaine}

Of these studied mummies, only the hair of the IQU-95 group was tested for the presence of cocaine. This compound was present in three of the six adults tested. A large population study of mummies from this region (Cartmell et al. 1991) found no cocaine in the hair of coastal people prior to 3,000 BP. Positive results appeared first in members of the Alto Ramirez culture shortly after 3,000 $\mathrm{BP}$ and were present in about half of adults in the following cultural groups. Langsjoen (1996) also found a close relationship between evidence of coca leaf-chewing practices and premature antemortem molar tooth loss (relative risk 22.0 above age 40), as did Indriati (1998) in living coca leaf-chewers in the altiplano. Consistent with this observation is the fact that the three IQU-95 mummies with 
negative cocaine hair tests collectively lost only 4 teeth antemortem while the three with positive tests for cocaine lost 10 .

\section{Tuberculosis}

The skeletal lesions of the SR-1 mummy suggested tuberculosis. However, several different infectious diseases including brucellosis, blastomycosis and coccidioidomycosis can mimic these lesions (Aufderheide and Rodriguez-Martin 1998:216). The employment of aDNA chemistry enabled the specific identification of the presence of the tubercle bacillus in these lesions, establishing this diagnosis with certainty. This case has been published previously (Arriaza et al. 1995).

\section{Diet}

The infants' isotopic values reflect its extremely high lipid diet as a nursling. The diet of the remainder, estimated by subtracting the (+9.4) fractionation value (Ambrose et al. 1997) from the $\delta^{13} \mathrm{C}$ values of bone apatite, indicates whole diet values clustered in a range between -14.9 and $-19.4 \%$. Values between -18.0 and $-19.0 \%$ o would reflect about half the diet was composed of $\mathrm{C} 4$ and half of $\mathrm{C} 3$ plants. Values between -12.0 and $-18.5 \%$ o suggest a predominance of $\mathrm{C} 4$ dietary components. At these sites $\mathrm{C} 4$ components would include marine meat and/or maize components. The high $\delta^{15} \mathrm{~N}$ values suggest that most of the $\mathrm{C} 4$ dietary components were derived from marine resources (fish, shellfish and sea lion meat). Thus these values suggest that the diet of most of these mummies was composed of a generous quantity of terrestrial plants of which maize constituted only a minor fraction, supplemented by abundant marine resources.

\section{Summary of Findings}

\section{Cultural information generated by the studies of these bodies}

1. Radiocarbon dates identified both time period and cultural identity.

2. Extended burial position of one body suggested it was a member of the Chinchorro cultural group, consistent with its radiocarbon date.
3. Bilateral exostoses of the external auditory canal (probably reflecting ocean diving activities) in several males.

4. Coca leaf-chewing practice (or ingestion) was established in several mummies.

\section{Biomedical information generated by the study of these bodies}

1. Severe osteopenia was present in three mummies, one with related vertebral compression fractures.

2. Premature antemortem tooth loss was found in three mummies, perhaps related to coca leafchewing practices.

3. Multiple examples of pneumonia with complete healing (pulmonary adhesions) were identified.

4. Multiple examples of Chagas disease (American trypanosomiasis), both in the acute and chronic phases were found by aDNA analyses.

5. Dilated cardiomyopathy due to Chagas disease was present in one body.

6. Tuberculous osteomyelitis of multiple bones was evident in two mummies and confirmed by aDNA analysis. One individual presented with evidence of systemic septicemia and multiple bone involvement also tested positive for aDNA of the Mycobacterium tuberculosis-complex.

\section{Conclusions}

The above list is testimony that our hypothesis has been supported. Multiple cultural features were derived that can be integrated into the anthropological database. Similarly, several major biological features were extracted from these bodies and these fit well into the general biomedical database.

Particularly valuable was the fact that determination of the time period of each individual body's death enabled establishment of the specific cultural identity of each body. Burial position was also helpful in identification of the cultural group (late Chinchorro) to which one of the bodies belonged.

The findings in these studied mummies fit comfortably into the context already created by the many other mummy studies previously reported. Studies of mummified human remains have generated a quantum of unique information that greatly expanded our understanding of these ancient populations. The identification and description of elaborate 
mummification practices by the early coastal settlers, the Chinchorro people, (Allison et al. 1984; Arriaza 1995) nearly 7,000 years ago provided perspective for the purpose of its practice in Egypt 2,000 years later (Aufderheide 2003:chapter 2). Similarly, Andean mountaintop mummies clarified Incan religious concepts (Reinhard 1996). Dietary data derived from coprolite studies documented a dramatic change in the interaction between coastal and highland populations about 3,000 BP, in which the largely coastal marine diet was relatively abruptly altered by one involving a mixture of agriculture and pastoral components (Aufderheide and Allison 1995). The presence of fish tapeworm ova in coastal mummy coprolites established that they ate their marine foods uncooked (Reinhard and Aufderheide 1990). Demonstration of the presence of cocaine in South American mummy hair contributed to the tracing of the spread of coca leaf use from the eastern jungle region to the western coastal peoples (Cartmell et al. 1994).

In addition to cultural features, mummy studies have also defined the health status of ancient populations. Case reports have enumerated a litany of diseases including bladder stones, gall stones, kidney diseases and a host of infections. In 1994 the aDNA of the tubercle bacillus was demonstrated in the lung of a 1,000-year-old female mummy near Arica, Chile (Salo et al.1994). This settled the controversial question of whether tuberculosis preceded the arrival of Europeans in the New World.

More recently the numbers of mummy tissue samples has accumulated to the level permitting population studies. These demonstrated that pneumonia was a major threat to survival, especially during infancy (Allison 1984). A study of tissue samples from about 300 mummies from northern Chile's ancient coastal populations indicated that $41 \%$ of those populations were infected by the fatal trypanosomal parasite that causes Chagas disease (Aufderheide et al. 2004). These are of special interest because, while case reports are valuable, they can only rarely test hypotheses, without which a scientific discipline cannot expand its knowledge base.

The mummies reported in this article are of considerable value. Lacking cultural identification, they would be useful only as individual case reports. With such identification established by radiocarbon dating, however, each can be included within the cultural groups of which they were a member. Thus they can expand those databases that deal with such groups' diseases - those of Chagas disease, cocaine-containing hair and its probably related molar tooth loss, tuberculosis, septicemia, auditory canal exostoses and poorly calcified bones. Each of those ancient diseases among specified cultural groups has been supplemented by the data extracted from these studied mummies. In this way they help make the all-important population studies possible. In this age of a global trend toward progressively decreasing access to mummies for study, these and every other individual mummy can make highly valued contributions to our continuing efforts to better understand our ancestors.

\section{References Cited}

Allison, M.J.

1984 Paleopathology in Peruvian and Chilean populations. In Paleopathology at the Origins of Agriculture, edited by M. Cohen and G. Armelagos, pp. 515-529. Academic Press, New York.

Allison, M.J., G. Focacci, B. Arriaza, V. Standen, M. Rivera and J.M. Lowenstein

1984 Chinchorro, momias de preparación complicada: métodos de momificación. Chungara 13:155-173.

Ambrose, S.H.

1993 Isotopic analysis of paleodiets: Methodological and interpretive considerations. In Investigations of Ancient Human Tissue, edited by M. Sandford, pp. 59-130. Gordon and Breach Science Publishers, Langhorne, Pennsylvania.

Ambrose, S.H., M. Butler, D. Hanson, R. Hunter-Anderson and H.W. Krueger

1997 Stable isotopic analysis of human diet in the Marianas Archipelago, Western Pacific. American Journal of Physical Anthropology 104:343-361.
Arganaraz, R., G.B. Hubbard, L.A. Ramos, A.L. Ford, N. Nitz, M.M. Leland, J.L. Vandeberg and A.R.L. Teixeira 2001 Blood-sucking lice may disseminate Trypanosoma cruzi infection in baboons. Revista do Instituto de Medicina Tropical de São Paulo 43(5):271-276.

Arriaza, B.

1995 Beyond Death. The Chinchorro Mummies of Ancient Chile. Smithsonian Press, Washington D.C.

Arriaza, B., W. Salo, A.C. Aufderheide and T. Holcomb 1995 Pre-Columbian tuberculosis in northern Chile: Molecular and skeletal evidence. American Journal of Physical Anthropology 98:37-45.

Aufderheide, A.C.

2003 The Scientific Study of Mummies. Cambridge University Press, Cambridge.

Aufderheide, A.C. and M.J. Allison

1995 Chemical dietary reconstruction of northern Chile prehistoric populations by trace mineral analysis. Proceedings 
of the First World Congress on Mummy Studies. Museo Arqueológico y Etnográfico de Tenerife, Organismo Autónomo de Museos y Centros, Cabildo de Tenerife, Santa Cruz de Tenerife.

Aufderheide, A.C. and C. Rodriguez-Martin, editors 1998 The Cambridge Encyclopedia of Human Paleopathology. Cambridge University Press, Cambridge.

Aufderheide, A.C., W. Salo, M. Madden, J. Streitz, J. Buikstra, F. Guhl, B.Arriaza, C. Renier, L. Jr. Wittmers, G. Fornaciari and M. Allison

2004 A 9,000-record of Chagas disease. Proceedings of the National Academy of Science 101(7):2034-2039.

Cartmell, L., A. Aufderheide, A. Springfield, C. Weems and B. Arriaza

1991 The frequency and antiquity of prehistoric coca-leafchewing practices in northern Chile: A radioimmunoassay of a cocaine metabolite in human-mummy hair. Latin American Antiquity 2:260-268.

Cartmell, L., A. Aufderheide, A. Springfield, J. Buikstra, B. Arriaza and Ch. Weems

1994 Análisis radio-imnunológico de cocaína en cabellos de momias del sur del Perú y norte de Chile. Chungara 26:125-136.

Genovés, $\mathrm{S}$.

1967 Proportionality of the long bones and their relation to stature among Mesoamericans. American Journal of Physical Anthropology 26:66-77.

Hearne, S.

1958 Journey to the Northern Ocean. Edited by R. Glover. McMillan, New York.

Indriati, E.

1998 A Dental Approach to Coca Leaf-Chewing in the Andes. A dissertation submitted to the faculty of the Division of the Social Sciences in candidacy for the degree of Doctor of Philosophy, Department of Anthropology, Chicago, Illinois.
Langsjoen, O.M.

1996 Dental effects of diet and coca leaf-chewing on two prehistoric cultures of northern Chile. American Journal of Physical Anthropology 101:475-489.

Moragas, C.

1995 Desarrollo de las comunidades prehispánicas del litoral Iquique-desembocadura río Loa. Hombre y Desierto 9:6580.

Reinhard, J.

1996 Peru's Ice Maiden: Unwrapping the Secrets. National Geographic 189(6):62-81.

Reinhard, K.J. and A.C. Aufderheide

1990 Diphyllobothriosis in Pre-Columbian Chile and Peru (Abstract). In Papers on Paleopathology, edited by E. Cockburn. Presented at the Eighth European Members Meeting of the Paleopathology, Cambridge.

Reinhard, K.J., U.E. Confalonieri, B. Herrmann, L.F. Ferreira and A.J.E. de Araujo

1986 Recovery of parasite remains from coprolites and latrines: aspects of paleoparasitological technique. Homo 37:217-284.

Salo, W.L., A.C. Aufderheide, J. Buikstra and T.A. Holcomb 1994 Identification of Mycobacterium tuberculosis DNA in a Pre-Columbian mummy. Proceedings of the National Academy of Sciences 91:2091-2094.

Standen, V., B. Arriaza and C. Santoro

1995 Una hipótesis ambiental para un marcador óseo: la exostosis auditiva externa en las poblaciones humanas prehistóricas del desierto del norte de Chile. Chungara 27:99-116.

Ubelaker, D.H.

1999 Human Skeletal Remains, Third Edition. Taraxacum, Washington, D.C.

Zink, A.R., W. Grabner, U. Reischl, H. Wolf and A.G. Nerlich 2003 Molecular study on human tuberculosis in three geographically distinct and time delineated populations from ancient Egypt. Epidemiology and Infection 130:239-49. 
